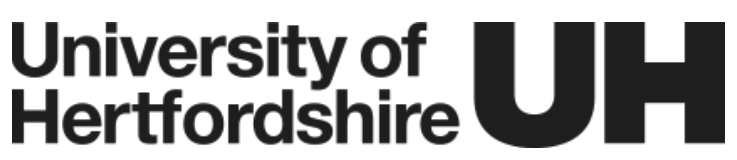

\section{Citation for the published version:}

Bourne, C. (Ed.), Caddick Bourne, E. (Ed.). (2018). Conversational Perversions, Implicature and Sham Cancelling in Othello. The Routledge Companion to Shakespeare and Philosophy.

\section{Link to the final published version available at the publisher:}

This is an Accepted Manuscript of a book chapter published by Routledge/CRC Press in the Routledge Companion to Shakespeare and Philosophy on 26/10/2018, available online: https://www.routledge.com/The-Routledge-Companion-toShakespeare-and-Philosophy/Bourne-Bourne/p/book/9781138936126

\section{General rights}

Copyright $\odot$ and Moral Rights for the publications made accessible on this site are retained by the individual authors and/or other copyright owners.

Please check the manuscript for details of any other licences that may have been applied and it is a condition of accessing publications that users recognise and abide by the legal requirements associated with these rights. You may not engage in further distribution of the material for any profitmaking activities or any commercial gain. You may freely distribute both the url (http://uhra.herts.ac.uk/) and the content of this paper for research or private study, educational, or not-for-profit purposes without prior permission or charge.

\section{Take down policy}

If you believe that this document breaches copyright please contact us providing details, any such items will be temporarily removed from the repository pending investigation.

\section{Enquiries}

Please contact University of Hertfordshire Research \& Scholarly Communications for any enquiries at rsc@herts.ac.uk 


\title{
Conversational Perversions, Implicature and Sham Cancelling in Othello
}

\author{
Craig Bourne and Emily Caddick Bourne
}

\begin{abstract}
Othello demonstrates what we call 'conversational perversions'. This is a technical term which we introduce to identify conversational behaviours which are designed to block the possibility of mutual understanding that characterises successful communication. We believe that our notion of a conversational perversion can be put to work to illuminate conversational encounters in general, but here we show, in particular, how Othello furnishes examples of conversational perversions and, in turn, how the notion of a conversational perversion can be used to articulate a major driver of the play's narrative: Iago's manipulation of Othello.
\end{abstract}

We explain the background, Gricean communicative framework, and how it relates to our framework for thinking about perversion. We illustrate our preferred account of perversion using the examples of sexual sadism and sexual coyness. We explain how to extend this account of perversion to cover conversational coyness and sadism. Finally, we identify how Iago's (and Othello's) ways of communicating exemplify these conversational perversions. In the course of this, we argue that Iago can be seen as making use of a perverted treatment of conversational implicatures, which we call 'sham cancelling'.

\section{Main Text}

\section{Overview}

Othello demonstrates what we call 'conversational perversions'. This is a technical term which we introduce to identify conversational behaviours which are designed to block the possibility of mutual understanding that characterises successful communication. We believe that our notion of a conversational perversion can be put to work to illuminate conversational encounters in general, but 
Published as Chapter 6 of Craig Bourne and Emily Caddick Bourne, eds. The Routledge Companion to Shakespeare and Philosophy (Routledge, 2018)

here our task is to show, in particular, how Othello furnishes examples of conversational perversions and, in turn, how the notion of a conversational perversion can be used to articulate a major driver of the play's narrative: Iago's manipulation of Othello.

In order to reach the payoff of the idea of conversational perversion for the study of Shakespeare, we need to present the notions which underpin it. First, we explain the background communicative framework, and then the notion of a perversion. We illustrate our preferred account of perversion using the examples of sexual sadism and sexual coyness. We explain how to extend this account of perversion to cover conversational coyness and sadism. Finally, we identify how Iago's (and Othello's) ways of communicating exemplify these conversational perversions. In the course of this, we argue that Iago can be seen as making use of a perverted treatment of conversational implicatures, which we call 'sham cancelling'.

\section{The Communicative Framework}

In communication, one of the things we aim for is a reciprocal relationship between speaker and hearer. In successful communication, speaker and hearer are each aware of certain psychological states in the other:

(a) The hearer is aware of some of the speaker's psychological states - and of how the speaker means to affect some of the hearer's own psychological states.

(b) The speaker is aware of how to get the hearer to recognise some of the speaker's own psychological states, and of how this is likely to affect some of the hearer's psychological states.

According to Paul Grice (1957), the relevant psychological states are beliefs and intentions. What a speaker does, in order to communicate, is to exercise intentions to influence the hearer's beliefs in a particular way, as captured by what we shall call the 'basic Gricean mechanism': 
Basic Gricean mechanism: A intends that B acquire a belief that $p$ on the basis of B recognising A's intention that B acquire a belief that $p$.

The core idea of this account of communication is that interpreting a speaker, i.e. working out what they mean, involves assuming that they satisfy the basic Gricean mechanism. The hearer interprets the speaker by working out what intentions the speaker is trying to get the hearer to recognise. This can be straightforward to do, or it can be complex.

When a hearer interprets a speaker, they have a default expectation that the speaker adheres to certain standards which govern our communicative exchanges in general (Grice (1975)). Those involved in conversation should engage in the appropriate way to meet the demands of the exchange. Grice calls this the Co-operative Principle. He proposes that four categories of maxims for rational co-operation fall within this general principle:

- maxims of quantity: provide the right amount of information (e.g. do not say too much; do not say too little);

- maxims of quality: give the hearer information in a reliable and trustworthy way (e.g. do not say what you know to be false; do not say that for which you have no evidence);

- maxims of relation: respect the focus of the conversation (e.g. make your contributions relevant);

- maxims of manner: construct your conversational contribution appropriately (e.g. avoid obscurity, prolixity, and ambiguity; be orderly in your delivery of information).

When one party is seemingly not being co-operative, and is doing so openly, then they should be interpreted as communicating something without actually saying it. This, according to Grice, explains why there can be conversational contributions that are not strictly said, but are 'implicated'. What a speaker 'implicates' in such cases is whatever is needed in order to reconcile the apparently uncooperative contribution with the Co-operative Principle. 
The notion of implicature can be illustrated using Grice's famous example of a referee who writes, in a reference for an academic position, that the candidate 'has very neat handwriting'. This is all that is said about the candidate. The reference is supposed to focus on academic expertise, so this seems to be an irrelevant contribution, which also provides too little information. To reconcile the statement with the maxims of relation and quantity, we have to assume that the referee is being as relevant and as informative as it is possible to be within the remit of the referee's task, which is to say positive things about the candidate. So the referee has used her utterance of 'He has very neat handwriting' to implicate that the candidate is not suitable for the position.

This suffices to introduce the communicative framework we will be employing to articulate the notion of conversational perversion. The next step is to outline the account of perversion we will employ.

\section{Perversion}

In Thomas Nagel's (1969) account, sexual perversion is given a psychological basis (rather than e.g. a physiological basis). He suggests understanding sexual perversion as something which thwarts the reciprocal awareness and recognition involved in what he calls a 'complete' sexual encounter. In the course of expounding his view of sexual perversion, Nagel makes the following observation:

'...reflexive mutual recognition is to be found in the phenomenon of meaning, which appears to involve an intention to produce a belief or other effect in another by bringing about his recognition of one's intention to produce that effect. (That result is due to H. P. Grice, whose position I shall not attempt to reproduce in detail.) Sex has a related structure: it involves a desire that one's partner be aroused by the recognition of one's desire that he or she be aroused.' (Nagel (1969: 12))

Nagel's observation is made in passing, and he does not explore the ramifications of the idea that the two structures are related, but we think it is key to articulating the possibility of perversion in the 
Published as Chapter 6 of Craig Bourne and Emily Caddick Bourne, eds. The Routledge Companion to Shakespeare and Philosophy (Routledge, 2018)

sexual as well as the conversational case. The structure Nagel identifies is a sexual analogue of the basic Gricean mechanism. We shall refer to it as the 'basic Nagelian mechanism':

Basic Nagelian mechanism: A desires that B become aroused on the basis of B recognising A's desire that B become aroused.

This gives rise to a definition of perversion where a sexual act is perverted if, by its very nature, it does not allow for the instantiation of the basic Nagelian mechanism. For instance, an act that involves selecting a sexual partner that one thinks is incapable of recognising one's desire - such as bestiality - is perverted for that reason. ${ }^{1}$

Nagel sometimes deviates from this definition in his discussion of various perversions - for instance, sometimes invoking a slightly different concept of 'naturalness' - and he develops a particular understanding of recognition which is not essential to the mechanism. Our own view is that by abstracting the basic Nagelian mechanism from other elements of Nagel's framework, a unified and comprehensive account of sexual perversion can be given. The full argument for this cannot be given here, but we will concentrate on how to apply the basic Nagelian mechanism to articulate two perversions that are of particular interest for the case of Othello: sadism and coyness.

\subsection{Sadism as a Perversion}

When person A satisfies the basic Nagelian mechanism, A desires that A's sexual partner be aroused on the basis of recognising A's desire that he or she be aroused. We propose that the way to pinpoint the source of the perversion in sadism is to focus on what is needed in order for a person to recognise a desire that they be aroused: this desire must be demonstrated to them.

Sadistic actions do not demonstrate a desire that the other person be aroused. Instead, they demonstrate a desire that the partner suffer or that they be hurt or humiliated (for example), rather 
Published as Chapter 6 of Craig Bourne and Emily Caddick Bourne, eds. The Routledge Companion to Shakespeare and Philosophy (Routledge, 2018)

than that they be aroused. By not demonstrating the desire that the other person be aroused, the sadist blocks the other person from recognising that desire in them.

Thus, in choosing sadistic acts, a person does not desire that they demonstrate, to their partner, the desire that the partner be aroused, and so does not desire that the partner recognise a desire that they be aroused. The desire that the partner be aroused on the basis of recognising the desire that they be aroused is therefore missing, and the basic Nagelian mechanism is not instantiated.

\subsection{Coyness as a Perversion}

Coyness seems to involve a deliberate departure from the basic Nagelian mechanism. In acts of coyness, the desire to arouse is disguised, so that the sexual behaviour seems innocent. Not all coyness constitutes sexual perversion, however. Take flirtatious coyness. Suppose John is aware that Lewis is being coy, and Lewis is aware that John is aware that Lewis is being coy. Lewis's attempt to disguise his desire to arouse John is in fact a complex way of indicating his desire to arouse John. Since Lewis does desire that John recognise Lewis's desire that John be aroused, and that he become aroused on this basis, this flirtatious case of coyness does not count as a perversion on our model.

Some cases of coyness, though, do constitute perversions. Suppose Mark is aroused by Spencer and he wants to arouse Spencer. But he wants Spencer not to recognise Mark's desire to arouse him, and he also wants Spencer to be unaware that he (Mark) is being coy, and to interpret his behaviour as innocent. Mark wants to conceal from Spencer any desire that he (Spencer) be aroused; if Spencer were to recognise Mark's desire, it would spoil Mark's enjoyment of the encounter. Mark does not instantiate the basic Nagelian mechanism, because he does not have the desire that Spencer become aroused on the basis of recognising that Mark desires Spencer to be aroused. Mark's coy acts therefore count as perverted. 


\subsection{Relations Between Coyness and Sadism}

Both sadism and coyness (of the non-flirtatious kind) involve blocking the possibility of one's partner recognising a desire that they be aroused. But in sadism, this is typically done by demonstrating a different desire, e.g. that the partner be hurt, whereas in coyness (of the non-flirtatious kind), this is typically done simply by appearing not to have the desire.

Note that there can be:

(a) A sadistic form of coyness: e.g. if Mark desires to distress or humiliate Spencer by appearing that he does not want Spencer to be aroused.

(b) A coy form of sadism: e.g. if somebody engaged in a sadistic act also conceals their desire that their partner suffer.

(c) A coy form of the sadistic form of coyness: e.g. if Mark has, but conceals, a desire to distress or humiliate Spencer by appearing that he does not want Spencer to be aroused.

We shall see later that some of Iago's conversational contributions combine conversational coyness and conversational sadism in analogous ways.

\section{Conversational Perversions}

Our proposal is that using the structural similarity between conversational and sexual encounters (i.e. the parallel between the basic Nagelian mechanism and the basic Gricean mechanism), we can define various conversational perversions corresponding to the taxonomy of sexual perversions. For the purposes of this paper, we are focussing on sadism and coyness. Recall that the basic Gricean mechanism captures a structure in which conversation partners are to interpret each other in terms of 
recognition of intention: A intends to induce in B a belief that $p$ on the basis of B recognising A's intention to induce in B a belief that $p$. The ways in which we attribute intentions to each other in conversation are described by the Co-operative Principle and the maxims of rational co-operation which fall within it.

These conversational standards can be exploited by a speaker in ways which deliberately block or disrupt the ways in which a hearer tries to recognise the speaker's intention to get them to believe that $p$. This we call a 'conversational perversion'. For example, take a speaker who deliberately says things which they know the hearer does not have the expertise to understand - perhaps by choosing obscure specialist terminology. What the speaker chooses to say is selected precisely because the hearer cannot identify what beliefs they should acquire and cannot respond suitably in the conversation. We say this is an instance of 'conversational sadism'. The sadist does not intend that the hearer acquires a belief on the basis of recognising their intention - rather, they intend that the hearer feels they cannot judge what the sadist's intentions are. (Such failure to understand is often humiliating, so we should expect a link between sadism and inflicting humiliation.)

It goes beyond the scope of this paper to show how moods other than the indicative are accommodated within the Gricean account of communication in general, but it is easy to illustrate how conversationally perverted uses of, say, questions are possible. Here is a pertinent case of conversational sadism. In the BBC comedy The League of Gentlemen, Pauline is a character whose job is to give training classes to jobseekers to help them find employment. She has contempt for her students and frequently bullies and insults them. In one roleplaying exercise, she plays the role of an interviewee, and one of the students - Ross, who knows he is much cleverer than Pauline, and is fed up with Pauline's attitude towards her students - takes the role of the interviewer. During the mock interview, Ross asks:

Ross Would you say you're a fairly egregious person? 
Published as Chapter 6 of Craig Bourne and Emily Caddick Bourne, eds. The Routledge Companion to Shakespeare and Philosophy (Routledge, 2018)

$$
\begin{array}{ll}
\begin{array}{l}
\text { Pauline } \\
\text { Ross }
\end{array} & \text { Are you an egregious person? Do you have an egregious personality? } \\
\text { Pauline } & \text { Um... yeah. Yeah, I do. }
\end{array}
$$

Ross has chosen his questions because he knows that Pauline does not know what 'egregious' means. He gives her no resources that might help her guess at an interpretation, especially as Ross introduces misleading elements, such as the idea of being 'fairly' egregious.

Before we consider Iago's conversational perversions in detail, two notes are in order. First, on our account, conversational and sexual perversions are interpersonal flaws. Whether they are also moral flaws differs case by case. Clearly, in Iago's case, conversationally perverted behaviours are used to immoral ends, but this immorality is not, in our view, where the perversion as such lies. Second, what should be deemed 'perverted' or 'non-perverted' are particular conversational contributions. An extended conversation may well be made up of perverted and non-perverted contributions (just as in the sexual analogue). Indeed, it is probably essential to the success of Iago's destruction of Othello that not all Iago's contributions to conversation with Othello be conversationally perverted, since if Othello were consistently unable to attribute intentions to Iago, he may simply stop engaging in trying to work out what Iago could be telling him. ${ }^{2}$

\section{Iago's Conversationally Perverted Contributions}

\subsection{Conversational coyness in Act 3, Scene 3}

Let us see how Iago blocks Othello from successfully attributing communicative intentions to him in the following exchange (3.3.35-41):
Iago
Ha! I like not that.
Othello
What dost thou say?
Iago
Nothing, my lord: or if - I know not what. 
Published as Chapter 6 of Craig Bourne and Emily Caddick Bourne, eds. The Routledge Companion to Shakespeare and Philosophy (Routledge, 2018)

\author{
Othello Was not that Cassio parted from my wife? \\ Iago Cassio, my lord! No, sure, I cannot think it, \\ That he would steal away so guilty-like, \\ Seeing you coming. ${ }^{3}$
}

Iago intends Othello to believe that something is wrong when he hears Iago say 'I like not that'. The way he disguises this intention is to behave - in saying 'Nothing' - as if Othello had not been an intended audience for the original comment at all. Moreover, immediately after claiming he had not been making a conversational contribution ('Nothing'), he nevertheless goes on to encourage Othello to consider what he had meant.

In his next contribution ('Cassio, my lord! No, sure, I cannot think it...'), Iago uses the fact that what he says either entails or presupposes that someone is behaving in a guilty way to induce in Othello the belief that Cassio is behaving in a guilty way whilst ostensibly denying that it is Cassio. Here, Iago intends his contribution to give Othello the belief that Cassio is behaving suspiciously, but intends for Othello to form that belief in a way which denies that this is Iago's intention.

Iago is also able to exploit maxims of co-operative conversation in ways that violate the basic Gricean mechanism. Consider Othello's reasoning (3.3.119-121) that:

\footnotetext{
And for I know thou'rt full of love and honesty

And weigh'st thy words before thou givest them breath,

Therefore these stops of thine fright me the more
}

'Weighing' one's words may be taken to concern just judging their probable effects (e.g. how profitable or damaging they will be). But it may also relate to the maxims of quality (e.g. how warranted one is in putting forward the view the words express). Thus, this may be an example of how Iago exploits a maxim of quality: that it is not conversationally responsible to offer an idea when 
Published as Chapter 6 of Craig Bourne and Emily Caddick Bourne, eds. The Routledge Companion to Shakespeare and Philosophy (Routledge, 2018)

your evidence for it is scant or potentially overrated. Othello, in taking Iago to be co-operative, must infer that the reason for Iago not communicating is that to communicate would violate a maxim. This allows him to draw the conclusion that Iago's suspicion is of such gravity that the level of evidence required for speaking of it is high. Iago intends Othello to draw conclusions from the fact that the maxims are in place, but in a way which demands denying that Iago has communicated those conclusions. In other words, he wants Othello to draw the conclusion by reasoning that Iago is thinking something which he isn't in a position to say. He intends Othello to gain beliefs, but his way of inducing them is designed to make it impossible for Othello to attribute this intention to him, and thus Iago creates a block to Othello basing his belief on recognition of the intention of his partner in conversation. ${ }^{4}$

Another case of Iago exploiting principles of co-operative conversation is found in an earlier exchange. Iago and Othello have been talking about Cassio knowing of Othello's love for Desdemona when Othello was wooing her, and the conversation continues like this (3.3.100-106):

\begin{tabular}{|c|c|}
\hline Iago & I did not think he had been acquainted with her. \\
\hline Othello & $\mathrm{O}$, yes, and went between us very oft. \\
\hline Iago & Indeed! \\
\hline \multirow[t]{2}{*}{ Othello } & Indeed! ay, indeed: discern'st thou aught in that? \\
\hline & Is he not honest? \\
\hline Iago & Honest, my lord? \\
\hline Othello & Honest! ay, honest. \\
\hline Iago & My lord, for aught I know. \\
\hline Othello & What dost thou think? \\
\hline Iago & Think, my lord! \\
\hline
\end{tabular}

In general, Iago here prolongs the conversation whilst resisting contributing any substantive information. In continuing to engage Othello communicatively, Iago encourages Othello to take him 
as being conversationally co-operative; thus, each of Iago's contributions is taken by Othello to have a point. Yet Iago's responses fail to reveal any such point. That in itself is obstructive to Othello's efforts to understand Iago, but there is also something subtler in Iago's strategy. Iago does not allow Othello to choose between the various explanations there are of why he would be responding in this way. One option is for Othello to treat Iago as evasive: he is trying to avoid providing information because there is something that he could reveal but doesn't want to. Alternatively, Othello could take responses such as 'Honest, my lord?' and 'Think, my lord!' to express Iago’s confusion over what information Othello could be asking for, suggesting that he expects it should already be clear what he means. A third option is that Iago is perplexed precisely because Othello is supposing him to mean something when he didn't - he should not be taken to have suggested anything, whether by accident or by implicature, beyond what he has said, and the reason he is responding in an unhelpful way is that Othello is searching for information that was never there.

Of course, none of these is the real explanation for why Iago says what he does, since really his utterances are chosen so as to undermine Othello's confidence in his understanding of his own situation. But the way this is achieved, we suggest, trades on the various alternative explanations that are available from Othello's point of view (assuming that Othello, at this point, has not considered that Iago is deliberately being incomprehensible). Whether we should take these to initially present themselves to Othello as equally plausible options will depend on the performance; the text leaves all three explanations, and the weighting between them, open. (Indeed, this caveat applies to all the examples discussed in this chapter, since conversation is not just a matter of which words are spoken, but also of how.) What is important at this point is that because Iago's contributions to the exchange do not allow Othello to readily or definitively choose between these explanations, Othello is not in a position to attribute to Iago intentions corresponding to whatever beliefs about Cassio he might gain from the exchange. 
The best Othello can do is to venture a working hypothesis (3.3.106-116):

Othello Think, my lord!

By heaven, he echoes me,

As if there were some monster in his thought

Too hideous to be shown. Thou dost mean something:

I heard thee say but now, thou likedst not that,

When Cassio left my wife: what didst not like?

And when I told thee he was of my counsel

In my whole course of wooing, thou criedst 'Indeed!'

And didst contract and purse thy brow together,

As if thou then hadst shut up in thy brain

Some horrible conceit

'As if' is an apt expression here. The explanation Iago's behaviour appears to have cannot be conclusively posited. Rather than interpreting Iago with confidence, the most Othello can say is that it is 'as if' Iago should be understood in the way Othello chooses to understand him. ${ }^{5}$ The fact that Othello is making a choice of working hypothesis at this point also adds to the kind of manipulation of Othello that Iago undertakes when he later warns him to 'beware, my lord, of jealousy' (3.3.166). Iago explicitly cautions Othello that a jealous mind is prone to make false hypotheses: 'oft my jealousy/Shapes faults that are not' (3.3.148-149). And the interpretative hypothesis Othello has made, in choosing to explain Iago's conversational behaviour in terms of concealed information about some harm done to Othello by those he trusts, is a jealous one, pursuing the option that best confirms his fears. Insofar as Othello is capable of recognising that his interpretation of Iago is influenced by jealousy, he is faced with the fact that Iago has also warned him off making the interpretative hypothesis he does, by cautioning him against the stance that leads to choosing it. By effectively inviting and repelling the same interpretation, Iago once again knowingly places Othello in a position of not being able to understand him. 
Published as Chapter 6 of Craig Bourne and Emily Caddick Bourne, eds. The Routledge Companion to Shakespeare and Philosophy (Routledge, 2018)

Othello's working hypothesis in fact blends the idea that Iago is concealing something ('Too hideous to be shown') and the idea that he is revealing something ('Thou dost mean something'). 'Thou dost mean something' points towards a conversationally sadistic act on Iago's part. Othello has employed all the interpretative resources a hearer has available in order to try to interpret Iago, and has arrived at no meaning. Yet he maintains that there was a meaning there. If Iago's meaning lies beyond Othello's interpretation, then it is impossible for Othello successfully to play his conversational role as a hearer. Thus, he experiences himself as being disabled in his conversational role.

This also helps to characterise the nature of Iago's deception of Othello, since it shows something about where Othello's false beliefs come from. It is true that the conversation with Iago is a cause of Othello's beliefs about Desdemona. But the beliefs were not acquired through communication. When understanding what has been communicated becomes impossible, the only recourse Othello has left is to speculation about what information there was for him to gain from the conversation with Iago.

Is Iago's conversational behaviour, in general, characterised more by sadism or by coyness? By concealing his intention that Othello acquire beliefs about Desdemona and Cassio, Iago prevents Othello recognising that intention. This concealing is an instance of conversational coyness.

But it is also plausible that at times Iago wants Othello to wonder whether Iago is concealing an intention, i.e. to wonder whether Iago is being coy. He does not, however, want Othello to resolve this to the point where he is able to attribute to Iago intentions to give Othello particular beliefs. Iago may want Othello to be in a state where he believes that $p$, but cannot determine whether or not Iago intends him to believe that $p$. This is a particularly sophisticated type of conversational coyness. 
Published as Chapter 6 of Craig Bourne and Emily Caddick Bourne, eds. The Routledge Companion to Shakespeare and Philosophy (Routledge, 2018)

The sadistic form of conversational coyness is instantiated when Iago intends for his coy conversational contributions to perplex Othello and leave him disempowered as a hearer, that is, no longer able to interpret his conversation partner. And if Iago also wants Othello to be unable to attribute to him this intention to perplex, then this is an instance of a coy form of the sadistic form of conversational coyness.

\subsection{Cancelling Implicatures in Act 3, Scene 3}

Our next proposal is that there is a particular conversationally perverted strategy Iago uses that is of philosophical interest. It trades on the fact that conversational implicatures can be cancelled. To see what it is to cancel an implicature, suppose Grice's referee says 'He has very neat handwriting', but goes on to add 'which aids engagement with his important philosophical ideas'. The implicature that the candidate is not very good is cancelled, because an alternative explanation has been offered for the utterance 'He has very neat handwriting'; something has been said about why the handwriting is relevant. ${ }^{6}$

Iago makes use of this conversational resource, but in a way that is conversationally perverted. We shall first describe two cases of putative cancelling and then identify what qualifies them as conversationally perverted. The first example involves an implicature about Cassio (3.3.127-130):

Iago
Or those that be not, would they might seem none!
Othello
Iago

An implicature that Cassio may not be what he seems is generated by mentioning people who are not what they seem (whilst discussing Cassio), but is purportedly cancelled by an explicit statement about Cassio in which Iago is apparently content to judge that Cassio is what he seems. 
The second example involves an implicature about Desdemona (3.3.229-239):

$$
\begin{aligned}
& \text { Aago, there's the point: as - to be bold with you - } \\
& \text { Not to affect many proposed matches } \\
& \text { Of her own clime, complexion and degree, } \\
& \text { Whereto we see in all things nature tends - } \\
& \text { Foh! one may smell in such, a will most rank, } \\
& \text { Foul disproportion, thoughts unnatural. } \\
& \text { But pardon me: I do not in position } \\
& \text { Distinctly speak of her, though I may fear } \\
& \text { Her will, recoiling to her better judgement, } \\
& \text { May fall to match you with her country forms, } \\
& \text { And happily repent. }
\end{aligned}
$$

Here, Iago's 'I do not in position/Distinctly speak of her' purports to cancel an implicature that Desdemona in particular has 'a will most rank', as if to revert instead to a general claim about 'such' people.

With these two examples in mind, we suggest that there are at least three coy aspects to Iago's strategy of setting up and then purportedly cancelling implicatures.

1. Moving the goalposts. Iago shifts what Othello is entitled to assume about what Iago meant. Whilst all acts of cancelling involve some such shift, ordinarily the aim is to facilitate pinning down what the speaker's intentions were, whereas in Iago's case, the aim is to obstruct this. This resistance to being 'pinned down' disarms Othello's attempts to attribute intentions to Iago. How Iago achieves this is explained by the other two coy aspects of his strategy: 
2. Undermining what seemed to be the point of his earlier utterances. In the first case, Iago effectively makes his earlier contribution irrelevant by (purportedly) cancelling the implicature which made it relevant. Why consider people who are not what they seem, if they are going to be set aside in drawing a conclusion about Cassio? There was no conversational justification for Iago's comment other than to generate the implicature. If the implicature is cancelled, the original statement does not play a proper role in the conversation. By saying something which would seemingly make his earlier conversational contribution pointless, Iago coyly blocks Othello from interpreting his meaning.

The second case is less clear. On one reading, Iago is constructing an argument: choosing outside one's own 'clime, complexion and degree' normally signals psychological and ethical deviance; Desdemona is not psychologically and ethically deviant; therefore, Desdemona will retract her choice. In that case, cancelling the implicature does not make the earlier contribution impotent; rather, it enables it to play its role in the argument. On another reading, Iago's purported cancellation of the implicature serves as an outright rejection of his previous contribution, telling Othello to ignore it altogether; Iago presents himself as having gone too far, perhaps having failed to adhere to maxims of quality. Iago may be taking advantage of Othello's opinion that he is someone who is disposed to 'mince [a] matter,/Making it light to' his friends (2.3.252-253). Thus, in representing himself as softening the original claim, Iago adds plausibility to that claim in Othello's eyes. On this reading, Iago constructs a conversational situation where the contribution retains its force, but he retreats from it: Othello is left thinking that Iago's original contribution did adhere to maxims of quality, but that Iago misjudges that it did not because Iago's standards are compromised by the unsuitable demands his 'honesty and love' (2.3.252) places on the level of certainty needed to say something which condemns a friend. On a third reading, the ideas about 'Foul disproportion, thoughts unnatural' and about Desdemona's 'recoiling to her better judgment' are two distinct insults, and Iago's purported cancellation is bizarre in just the same way as his purported cancellation of the implicature that Cassio is not what he seems. His second point could have been made without the first, so if - as his purported 
Published as Chapter 6 of Craig Bourne and Emily Caddick Bourne, eds. The Routledge Companion to Shakespeare and Philosophy (Routledge, 2018)

cancellation suggests - it did not pertain to Desdemona, then there was nothing conversationally cooperative in saying it. For why consider 'foul disproportion', and so on, if not to apply what is being said to Desdemona?

In the second and third readings of the second case, and the proposed reading of the first case, what is most significant is that a residue of the implicature is left even after it has supposedly been cancelled. Thus, there is a clear rhetorical point to what Iago is doing, although it may be achieved by deliberately behaving in a way which seems to rob some of his utterances of their conversational point (by the standards of the maxims of co-operative conversation). The aim is to leave Othello unable to discard what seemed to be implicated, and yet unable convincingly to attribute it to Iago.

This leads us to the third aspect of Iago's strategy of coy cancelling:

3. Deliberately unconvincing cancelling. As a further illustration, consider this exchange, from an earlier point in the scene (3.3.94-99):

$\begin{array}{ll}\begin{array}{l}\text { Iago } \\ \text { Othello }\end{array} & \text { My noble lord,-- } \\ \text { Iago } & \text { Did Michael Cassio, when you woo'd my lady, } \\ & \text { Know of your love? } \\ \text { Othello } & \text { He did, from first to last: why dost thou ask? } \\ \text { Iago } & \text { But for a satisfaction of my thought; } \\ & \text { No further harm. }\end{array}$

Othello Why of thy thought, Iago?

Depending on how the question is delivered in performance, it may carry an implicature that there is something suspicious, or at least significant, about Cassio's situation. To reconcile Iago's utterance with maxims of relation, we must take it that it matters whether Cassio knew, implicating that the 
Published as Chapter 6 of Craig Bourne and Emily Caddick Bourne, eds. The Routledge Companion to Shakespeare and Philosophy (Routledge, 2018)

knowledge would be of some significance to Cassio, and that the way it is significant also affects Othello.

Iago, however, purports to cancel the (potential) implicature: he provides an explanation of why he said what he did which overrides the explanation which generated the implicature. What is key in understanding the dynamic of the exchange is that Iago does this in a deliberately unconvincing way. 'But for a satisfaction of my thought' purports to remove the need for Othello to draw whatever conclusions about Cassio might otherwise have been implicated by Iago's original question. But - as Iago knows - the new explanation he is offering does not explain the original utterance as well as the potential implicatures would, partly because it simply opens up the question - which Othello immediately goes on to ask - of why he would be thinking about that anyway. As such, Iago disclaims the original implicatures, but ensures that Othello continues to entertain them (because they remain the best explanation of why Iago said what he did).

Since Iago has not given Othello a good to reason to set aside, for the purposes of interpreting Iago, the thought that there is something suspicious about Cassio, we shouldn't quite say that this implicature has been cancelled, nor even that there has been an attempt to cancel the implicature. Rather, going through the motions of cancelling, whilst offering an explanation too weak to remove what was implicated from the hearer's beliefs, amounts to what we call 'sham cancelling'. Iago exploits the possibility of sham cancelling in order to influence Othello's beliefs in a coy way. He intends for Othello to believe that there is something suspicious about Cassio, but his sham cancellation instructs Othello not to attribute to Iago the intention that Othello have that belief.

Because the explanation offered in a sham cancellation is so weak, Iago allows Othello to go on thinking 'but that is what you meant'; but because Iago has gone through the motions of cancelling, 
Published as Chapter 6 of Craig Bourne and Emily Caddick Bourne, eds. The Routledge Companion to Shakespeare and Philosophy (Routledge, 2018)

Othello is also called on to reject that interpretation. Once again, creating this perplexity amounts to conversational sadism. Iago puts Othello in either:

(a) a state of uncertainty, where he is essentially unresolved about whether to attribute to Iago the intention to get him to believe certain things about Cassio and Desdemona, or:

(b) a state where he is both conversationally required to think that Iago intends him to believe certain things about Cassio and Desdemona, and conversationally required not to do this, because Iago eschews the intention. Iago's behaviour suggests: that is what I meant, and it isn't what I meant.

This also raises questions about who has responsibility for Othello's beliefs. Implicatures are a good example of how conversational responsibility is shared between the speaker and hearer, as the hearer has to make decisions about what would satisfy the maxims in order to construct the implicature behind what the speaker has said. Sham cancelling creates a peculiar dynamic of responsibility because the speaker has introduced an idea to the conversation and has then disowned it, but without successfully removing it, thus placing the burden on the hearer to either take it up or find a better explanation for why it should be discarded. ${ }^{7}$

\section{Morals}

Iago's use of language to disrupt Othello's peace of mind goes far beyond simply deceiving him or putting him in a state of jealous suspicion. We have argued that Iago epitomises conversationally coy behaviour, and his coyness comes in various forms, including conversationally sadistic forms. Iago does not always straightforwardly disguise his intentions, but sometimes encourages Othello to waver over whether to attribute them, or speaks in a way which requires Othello to create contradictory interpretations of what Iago means. 
We have focussed on just two conversational perversions - coyness and sadism - and just a few exchanges, from one play. To extend this to more of Shakespeare's works, and a wider variety of conversational perversions, whilst beyond the scope of this essay, is possible. What we hope this chapter demonstrates is how fruitful the idea of conversational perversion can be in understanding not just language, but also the dynamics of the drama.

\section{Coda: Conversational Perversions Beyond Iago}

To illustrate that conversational perversion is not unique to Iago, let us briefly touch on an exchange where Othello exhibits conversational perversion (4.2.24-33):

Othello Pray, chuck, come hither

Desdemona is your pleasure?

Othello Let me see your eyes;

Look in my face.

Desdemona What horrible fancy's this?

Othello [to Emilia] Some of your function, mistress,

Leave procreants alone and shut the door;

Cough, or cry hem, if any body come:

Your mystery, your mystery: nay, dispatch.

[Exit Emilia]

Desdemona Upon my knees, what doth your speech import?

I understand a fury in your words,

But not the words.

Othello's exclusion of Desdemona comes not just from silencing her (as a speaker), but from undermining her role as a hearer by making himself unintelligible to her. This is an instance of conversational sadism from Othello. ${ }^{8}$ 
Published as Chapter 6 of Craig Bourne and Emily Caddick Bourne, eds. The Routledge Companion to Shakespeare and Philosophy (Routledge, 2018)

\section{Related Topics}

See chapters $7,19,20$

\section{Further Reading}

Bourne, C. and Caddick Bourne, E., 2016. Time in Fiction, Chapter 4.

We discuss what Macbeth represents concerning the metaphysics of the future, including a discussion of Gricean conversational norms and Macbeth and Banquo's decision to treat the weird sisters' utterances as interpretable.

Grice, H.P., 1957. Meaning. The Philosophical Review 66: 377-88.

Grice gives an account of the distinction between natural and non-natural meaning and the relationship between speaker meaning and sentence meaning. He sets out what we have here called the 'basic Gricean mechanism'.

Grice, H.P., 1975. Logic and Conversation. In: P. Cole and J. Morgan, eds. 1975. Syntax and Semantics Vol.3. New York: Academic Press.

This is the classic source for Grice's maxims of rational co-operation, and the notions of conversational implicature and cancellability.

Nagel, T., 1969. Sexual Perversion. Journal of Philosophy 66: 5-17.

Nagel gives an account of sexual perversion in terms of behaviours which block the possibility of parties instantiating a particular structure of interpersonal psychological attitudes. The account of sexual perversion we utilise here is based on elements of this view. 
Published as Chapter 6 of Craig Bourne and Emily Caddick Bourne, eds. The Routledge Companion to Shakespeare and Philosophy (Routledge, 2018)

\section{References}

Bertucelli Papi, M., 1996. Insinuating: The Seduction of Unsaying. Pragmatics 6: 191-204.

Cavell, S., 2003. Disowning Knowledge in Seven Plays of Shakespeare. Cambridge: Cambridge University Press.

Grice, H.P., 1957. Meaning. The Philosophical Review 66: 377-88.

Grice, H.P., 1975. Logic and Conversation. In: P. Cole and J. Morgan, eds. 1975. Syntax and Semantics Vol.3. New York: Academic Press. Reprinted in Grice (1989). [Page numbers taken from (1989).]

Grice, H.P., 1978. Further Notes on Logic and Conversation. In: P. Cole, ed. 1978. Syntax and Semantics Vol.9. New York: Academic Press. Reprinted in Grice (1989). [Page numbers taken from (1989).]

Grice, H.P., 1989. Studies in the Way of Words. Cambridge, Mass.: Harvard University Press.

Keller, S.D., 2010. Combining Rhetoric and Pragmatics to Read Othello. English Studies 91: 398-411.

Kikuchi, S., 1999. I told him what I thought: Iago's 'lying' by implying. Studies in Modern English 15: $29-43$.

McGinn, C., 2006. Shakespeare’s Philosophy. New York: HarperCollins.

Nagel, T., 1969. Sexual Perversion. Journal of Philosophy 66: 5-17.

Shakespeare, W., 1941. Othello. Edited by H.C. Hart. Sixth Edition. The Arden Shakespeare. London: Methuen.

Vickers, B., 1993. Appropriating Shakespeare: Contemporary Critical Quarrels. New Haven, Conn.: Yale University Press. 


\footnotetext{
${ }^{1}$ An account of what it is to recognise someone's psychological states (such as desires or intentions) is beyond the scope of this paper. Here, we trade on the fact that there is something it is for recognition to be achieved, and that there are various ways in which this can fail, some of which are perversions.

${ }^{2}$ The term 'perversion' has been used in connection with Iago's language before. Vickers (1993), who also draws on a Gricean framework, writes, for example, that 'Since we alone have known from the beginning that Iago only serves for his own gain, when we see him professing to observe the
} Cooperative Principle and maxims, we alone know to what degree he is perverting them', and describes Iago as undertaking a 'silent perversion of trust' (80), as well as arguing that 'The continuum that Iago affirms between thought and speech as an index of love would indeed be a norm for sincerity in communication if he were not ... relentlessly perverting it' (86-7), and attributing to him a 'sustained perversion of the co-operation basic to all human communication' and a will 'that cannot bear not to fulfil itself in all its perverted energy and resourcefulness' (91). In this sense of 'perverting', Iago perverts the conditions for communication by sending them awry, distorting them, or playing tricks with them. Whilst trickery and distortion may well also be a feature of many conversational behaviours that are 'perverted' in our sense, we propose to take the idea of perversion more literally by identifying a particular structure which links conversational perversion to sexual perversion, and which allows for positing specific types of conversational perversion (such as sadism), similarly to in the sexual case. In this way, we make perversion the central linguistic concept for understanding the workings of Iago's conversational behaviour. Moreover, though conversational perversion in our sense does sometimes involve a failure to comply with one or more of Grice's four maxims, it can also arise in other ways. Finally, whilst the maxims falling under the Co-operative Principle will play an important role in articulating some of the instances of perversion we discuss, what is crucial to recognising the structure of perversion is, we argue, not so much Grice's account of the maxims, but the basic Gricean mechanism.

${ }^{3}$ Quotations are from Shakespeare (1941). 
${ }^{4}$ Other papers which discuss Othello in relation to Grice's maxims, or to alternative neo-Gricean or non-Gricean accounts of communication within the philosophy of language, include Bertuccelli Papi (1996), Kikuchi (1999), and Keller (2010). Although our argument and its aims differ from those at work in these papers, many of the instances analysed of Iago's communication are also focal examples for these other approaches. A reader who is sympathetic both to arguments within one or more of these papers, and to our own idea of conversational perversion, could use the accounts to complement each other in places.

${ }^{5}$ There is an affinity here with the discussion of scepticism concerning the content of others' thoughts (see e.g. Cavell (2003), McGinn (2006)). Of particular significance is the relationship between scepticism and deception. In many cases, deception trades on successful communication, since false beliefs are communicated. (Which is not to say they are stated. For further discussion of this in the case of Iago, see Dianne Rothleder's paper in this volume.) Our discussion adds a further dimension, however. By employing the notion of a conversational perversion, we see that Iago employs strategies to give Othello false beliefs that work not by successfully communicating those beliefs, but, on the contrary, by creating a block to successful communication, leaving Othello in a position where his ability to understand the conversational contributions of the other party is unseated. Note that this counts as a strategy to deceive (rather than only to confuse or to bemuse) only if Iago believes that Othello is likely to arrive at false beliefs in the process of attempting and failing to interpret his conversations with Iago.

${ }^{6}$ For more on Grice's account of cancelling, see his (1975: 39) and (1978: 44-46).

${ }^{7}$ Veli Mitova's chapter in this volume focuses on the topic of epistemic responsibility in Othello in its own right. Our point here is specifically about how Othello's (unfair) conversational responsibilities play into his epistemic responsibilities.

${ }^{8}$ We are grateful to David Austin for his perceptive comments on an earlier draft. Thanks also to the editors of this volume for their ingenious suggestions, and for spotting some embarrassing blunders; of course, they cannot take responsibility for any errors which remain. 